\title{
Motivation in Construction Innovation: Commercial Opportunities, Problem-Solving and Passion for Improvement
}

\author{
Chang Yean Fang ${ }^{1}$, Rajah Rasiah², Jane E. Klobas ${ }^{3}$ \\ ${ }^{1}$ Department of Business Strategy and Policy, Faculty of Business and Accountancy, University of Malaya, Kuala Lumpur, Malaysia \\ ${ }^{2}$ Department of Development Studies, Faculty of Economics and Administration, University of Malaya, Kuala Lumpur, Malaysia \\ ${ }^{3}$ Department of Business Strategy and Policy, Faculty of Business and Accountancy, University of Malaya, Kuala Lumpur, Malaysia
}

\begin{abstract}
This article analyses motivations for innovation in construction using the service sector adaptation of the Sectoral System of Innovation (SSI) framework. Interviews and site visits were conducted with four Malaysian firms. Innovation in construction is similar to the service sector. There is evidence of technology-push, capability-push and demand-pull; capability push is the most important. Construction firms innovate to gain commercial opportunities, to solve project-related problems and to improve processes. By simplifying construction work, process innovation saves time and costs, increasing efficiency and productivity, and providing increased competitiveness. Innovation is also motivated by committed and passionate actors within construction firm.
\end{abstract}

\section{Introduction}

Construction faces intense competition for international job opportunities (Abdul-Aziz \& Wong, 2010) with cross-national trade agreements and globalization providing developing countries with greater freedom of access to markets. Increasing sophistication in societal demands and environmental pressures bring increased demand for safer, higher quality and sustainable construction, creating a further challenge for policy makers. Against this backdrop of challenges, the construction industry worldwide faces problems in safety, quality and delays (Oakland \& Marosszeky, 2006), and a poor public image (Samuelsson, 2003).

Historically, innovation in the construction industry has been regarded as very conventional: innovation is incremental, and radical and revolutionary innovations are rare (Slaughter, 1998). In the mid-2000s, lack of investment in research and development (R\&D) was identified as the main cause of low innovation in construction in several countries, including the UK, Australia, Hong Kong and Singapore (Lim, 2006). Since then, increased attention has been paid to innovation in construction. Nonetheless, despite substantial investment and research, innovation remains rare in the construction sector. One explanation is that research on construction innovation has relied on theories and methods drawn from manufacturing, but because the construction industry is project-based and requires specific processes (Reichstein et al., 2005), this has hindered rather than aided efforts to understand innovation in construction (Koskela \& Vrijhoef, 2001).

To address this shortcoming, we adopt a new approach to study innovation in the construction industry.
The Service Sectoral Systems of Innovation framework developed by Tether and Metcalfe (2004) provides a systemic model of innovation for the services industry. We adapt this model to the construction industry to analyse the motivation for innovation of four Malaysian construction firms. The paper is organized as follows. The next section presents the theoretical arguments used to construct the analytic framework. The subsequent sections present the methodology followed by the findings. The paper concludes with a discussion and the final section presents the conclusions of the paper.

\section{Literature Review}

The need for new construction innovation theory

Shapiro (1999) provides a useful discussion of the differences between construction and manufacturing systems. She describes complex product systems (COPS) as systems which are produced on a project basis for specific customers and markets, and notes that their innovation and production processes differ from those assumed to exist in traditional research models based on manufacturing and mass production. COPS production processes stress software development, systems integration and project management over repeated tasks (Shapiro, 1999).

The COPS characteristics of construction mean that innovation in construction needs to be examined differently, using models other than the conventional models based on mass production in the manufacturing sector. Furthermore, the construction sector is more similar to the service sector than manufacturing with regards to innovative behaviour (Reichstein et al., 2005). 
Manufacturing models, if applied without modification, are unsuitable, conceptually and in terms of management strategy and practices (Acha et al., 2005; Reichstein et al., 2005; Widén, 2006; Widén, 2010). Existing construction research that is based on manufacturing models cannot provide a comprehensive account of the sector and, as a consequence, risks generating misleading findings about the industry.

Innovation in construction firms is influenced by a diversity of interrelated actors in a complex systemic network. To understand the factors that influence contractors' decisions to innovate one has to understand this complex system of innovation.

\subsection{Sectoral systems of innovation (SSI) theory}

The sectoral systems of innovation (SSI) approach of Malerba $(2002,2004,2006)$ permits the study of multifaceted non-linear interactions between actors involved in innovation across an industrial sector. The systemic view of the processes of innovation and diffusion of technology originated with Schumpeter (1961) and was later embraced by others. The SSI approach is rooted in the evolutionary economics school with antecedents to Veblen (1898), the founder of institutional economics. Evolutionary theory explains the origin and evolution of different industries and technologies as being shaped by time and locality (Malerba \& Nelson, 2011; Nelson, 2008). This approach is a good fit for the study of the construction industry in Malaysia, which differs by sector in different localities with different institutional regimes and by the timing of the evolution of the sector.

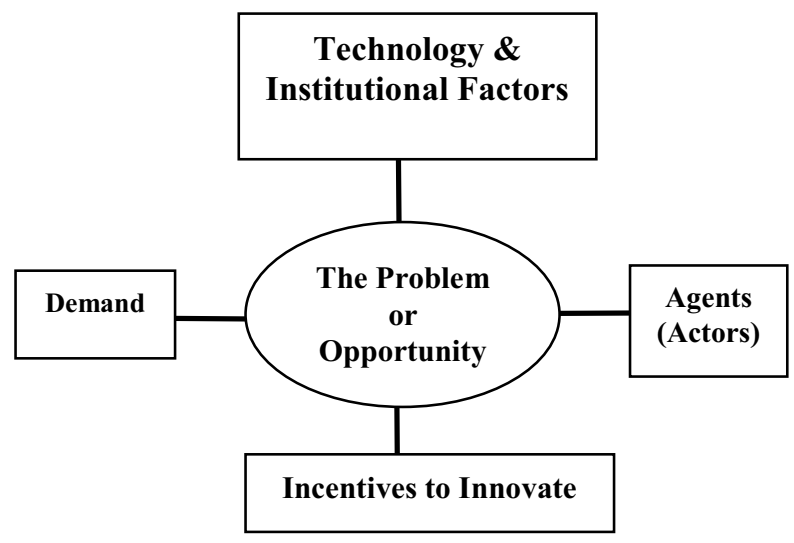

Figure 1: Problem-/Opportunity-Centric Innovation Tether \& Metcalfe, 2004)

\subsection{Innovation systems in the service sector (ISS) framework}

Tether and Metcalfe's (2004) application of the SSI to innovation systems in the service sector (ISS) incorporates propositions about motivations for innovation. Tether and Metcalfe suggest the use of problem and opportunity to examine the interactions and interdependencies, patterns of resistance to innovation, patterns of sources of knowledge, balances of dependency and power, and the relations of these characteristics with patterns of activities and innovation.

This paper adopts this approach. Thus, following Reichstein et al. (2005), we propose that innovations in services are developed around problems (or opportunities) that are framed by a number of contingencies - including the regulatory, cultural and technological context - demand, agents (actors) and incentives (Figure 1).

\subsection{Motivations for innovation in construction}

The construction industry literature points to three main motivators for innovation: client- or demand- pull; construction firm or capability push; and improvement in project performance. Arditi et al. (1997) Bossink (2004) and Tatum (1989) show that both the availability of technology (technology-push) and client demand (demand-pull) are relevant in the construction industry. However, Gann and Salter (2000) suggest that demand pull is the stronger motivator (Ling, 2003). Toole (1998) suggests that construction firms are motivated to innovate to improve project performance in terms of cost and the project's final structure or system. Empirical research indicates that innovation is pursued in construction generally to reduce costs, improve functionality and sustain market share (El-Mashaleh et al., 2006; Seaden et al., 2003; Thomas et al., 2004; Toole et al., 2013).

\section{Methodology}

Since the purpose of this paper is interpretative rather than predictive, we use case studies to examine the motivation for innovation in the construction industry (Yin, 2014). We selected four case studies using criteria for differentiation by sector and innovation-type defined by us and criteria for innovativeness suggested by the literature and experts from Malaysia's Construction Industry Development Board (CIDB). Because the firms requested confidentiality, we use pseudonyms to refer to them, namely, the infrastructure developer as InnoInfra, the residential buildings developer as InnoWEBS, and the constructors of commercial buildings as InnoInfo and InnoIBS.

We carried out a total of 19 interviews in Malaysia between October 2012 and January 2013 with personnel engaged in innovation in the selected firms. For analysis, we used the steps suggested by Hsieh and Shannon (2005) for data coding and thematic analysis.

\subsection{Case context}

Between them, the four firms were responsible for a total of seven innovations: a two-in-one infrastructure, which alleviates flooding with a tunnel which is also used for vehicular traffic; a connecting highway by building a bridge over an existing highway; large-scale public transport infrastructure; a building modelling and project management information system; two industrialized building systems; and a modular house that could be constructed by the consumer (the do-it-yourself or DIY 
house). Two innovations were more than nine years old, two were completed in 2010, and the other three were still on-going during the interviews.

Table 1: The Case Study Firms and Their Innovations

\begin{tabular}{|c|c|c|c|c|}
\hline $\begin{array}{l}\text { Case Study } \\
\text { Firm }\end{array}$ & Subsector & No & Innovation & $\begin{array}{l}\text { Inno- } \\
\text { vation } \\
\text { Age }\end{array}$ \\
\hline \multirow[t]{3}{*}{ InnoInfra } & \multirow[t]{3}{*}{$\begin{array}{l}\text { Civil } \\
\text { engineering }\end{array}$} & 1 & $\begin{array}{l}\text { Joint highway / } \\
\text { flood mitigation } \\
\text { infrastructure }\end{array}$ & 9 years \\
\hline & & 1 & $\begin{array}{l}\text { Connecting } \\
\text { highway bridge }\end{array}$ & $\begin{array}{l}17 \\
\text { years }\end{array}$ \\
\hline & & 1 & $\begin{array}{l}\text { Public transport } \\
\text { infrastructure }\end{array}$ & 6 years \\
\hline InnoInfo & $\begin{array}{l}\text { Building- } \\
\text { Commer- } \\
\text { cial }\end{array}$ & 1 & $\begin{array}{l}\text { Building } \\
\text { process } \\
\text { information } \\
\text { system }\end{array}$ & 6 years \\
\hline InnoIBS & $\begin{array}{l}\text { Building- } \\
\text { Commer- } \\
\text { cial }\end{array}$ & 2 & $\begin{array}{l}\text { Industrialized } \\
\text { building system }\end{array}$ & 1 year \\
\hline InnoWEBS & Residential & 1 & $\begin{array}{|lr|}\text { DIY } & \text { house } \\
\text { consisting } & \text { of } \\
\text { frame, wall, } \\
\text { roof systems }\end{array}$ & $\begin{array}{l}\text { On- } \\
\text { going }\end{array}$ \\
\hline
\end{tabular}

Two sources of innovations were observed: in two cases, the innovation idea originated from the construction firm itself; in the other two cases, the construction firm purchased the technology or solution for the innovation and customized it. When the idea originated in the construction firm, the owners and senior management initiated the idea then developed the innovation with external consultants. When the idea originated externally, the construction firms customized the technology, either according to company processes or to company or market needs. The extent of initial investment in technology and subsequent customization of the technology varied.

Both firm-led and externally provided innovations used existing solutions with incremental changes in technology. Thus, the innovations were imitations or adoptions of existing innovations with customization to suit the processes of the company and market needs. Contractor leadership was a key feature of innovation in two case study firms, thus, in construction, not all innovations can be deemed supplier-dominated. Further, in the two case studies involving a technology or solution provider, InnoInfo undertook extensive customization with a full-time team of R\&D staff and without the support of external solution providers. The observed innovations consisted of innovations in business practices, in the form of business strategy and business contracts (InnoInfra); organizational processes (InnoInfo); and both construction process and product characteristics (InnoIBS and InnoWEBS).
Table 2: Source and Type of Innovation in Case Study Firms

\begin{tabular}{|l|l|l|}
\hline $\begin{array}{l}\text { Firm and } \\
\text { Innovation }\end{array}$ & $\begin{array}{l}\text { Source of } \\
\text { Innovation }\end{array}$ & $\begin{array}{l}\text { Type of } \\
\text { Innovation }\end{array}$ \\
\hline $\begin{array}{l}\text { InnoInfra: } \\
\text { Highway (2), } \\
\text { Transportation }\end{array}$ & $\begin{array}{l}\text { Construction } \\
\text { firm-led }\end{array}$ & $\begin{array}{l}\text { Business } \\
\text { practice }\end{array}$ \\
\hline $\begin{array}{l}\text { InnoIBS: IBS } \\
\text { related } \\
\text { innovation }\end{array}$ & $\begin{array}{l}\text { Construction } \\
\text { firm-led }\end{array}$ & $\begin{array}{l}\text { Construction } \\
\text { process \& } \\
\text { product }\end{array}$ \\
\hline $\begin{array}{l}\text { InnoWEBS: } \\
\text { DIY house } \\
\text { consisting } \\
\text { frame, wall, roof } \\
\text { systems }\end{array}$ & $\begin{array}{l}\text { Technology } \\
\text { provider, some } \\
\text { customization }\end{array}$ & $\begin{array}{l}\text { Construction } \\
\text { process \& } \\
\text { product }\end{array}$ \\
\hline $\begin{array}{l}\text { InnoInfo: } \\
\text { Information on } \\
\text { building process }\end{array}$ & $\begin{array}{l}\text { Solution } \\
\text { provider, heavy } \\
\text { customization by } \\
\text { own full-time } \\
\text { R\&D staff }\end{array}$ & $\begin{array}{l}\text { Organizational } \\
\text { process }\end{array}$ \\
\hline
\end{tabular}

R\&D in the construction firms existed in a different form to the formal conventional R\&D of firms with fulltime staff and access to testing laboratories. Except for InnoInfo, development of the innovations occurred as part of the firms' technical work on feasibility studies rather than as a permanent, full-time function.

The length of the innovation cycle time depended on three factors. Where the innovation was more complex (infrastructure innovation at InnoInfra), the innovation cycle time was longer, taking up to two years. Where the contractor developed the innovation in-house, with little external support, the innovation cycle time was longer still, e.g. three years in the case of InnoInfo. Where the technology was purchased from a technology provider (InnoWEBS), the innovation cycle was short as the main development work had been completed by other parties. Where the innovation was required urgently (InnoIBS), the innovation cycle time took only a few weeks.

\section{Findings}

We observed the expected forms of motivation arising from problems and opportunities. In addition, we observed motivations due to the actions of top management, and the personal motivation of innovative owners.

\subsection{Problem- and Opportunity-Centric Motivation to Innovate}

We found evidence that construction firms, like firms in the service industry, innovate to solve problems or to seize a business opportunities in the market. Technical and business problems are seen as commercial opportunities or as a stimulus for improvement for internal practices and processes.

\subsubsection{Commercial problems and opportunities}


Firstly, the firm innovates to address a commercial problem or issue in the industry to find better ways of solving business and technical issues (InnoInfra, Corporate Director). Such issues include flood and environmental problems, transportation issues and water supply. Again, here was a problem [referring to the flood problem in Malaysia] so what could we do? This issue triggered a proposal from us. (InnoInfra, Corporate Director). Secondly, innovation is driven by a need for differentiation innovation in the company is driven by the need to differentiate ourselves in the industry. (InnoInfra, Corporate Director) as commercial strategy is driven by the need to show continuous growth in shareholder value necessity is the mother of all invention. We innovate because we have to. We need to show continual improvement in our business and grow shareholder value. To grow, we need to secure new projects, and to do so in a competitive and sometimes uncertain market, we need to think of new opportunities using out-of-the-box approaches. (InnoInfra, Corporate Director) in a fragmented supply chain. Why do we need to innovate software [A]? Because we don't have obvious competitive advantage and we are not differentiated. We are so fragmented; our supply chain is different. (InnoInfo, Innovation Manager)

In the past, members of InnoInfo's workforce, in common with the workforce of the construction industry as a whole, did not require professional qualifications. Its low level of human capital meant that InnoInfo's staff did not always take a professional approach to problem solving and was not sufficiently competitive. The firm was not able to attract new talent. The older generation of construction workers does not need qualifications and bangs tables [is less professional] in their work - this needs to change. Using IT is not to impress talents but overall in an industry we must be more competitive. (InnoInfo, Innovation Manager)

For InnoInfo, innovation enables the industry to remunerate talent. This will then attract talent to join the company, an important factor in ensuring its competitive advantage. Overall, according to the Innovation Manager of InnoInfo, the construction industry has not been able to attract talent due to its negative image of being "dirty, dangerous and difficult" as well as the less than professional behaviour of the older generation construction workers. He expects innovation to provide a more positive branding of the industry which will, in turn, enable InnoInfo to attract higher calibre human capital to the company.

The differentiation strategy of InnoWEBS acts as a competitive advantage strategy to the firm to recoup the expenditure in innovation and ultimately bring revenue to the firm. It is the excitement of knowing, but also we know we can make money. It is the combination of these two factors. At the end of it, it is about monies. We know that if we can capture that knowledge: first is what knowledge can do; two is that we need to recoup for monies spent to commercialize. (InnoWEBS, Managing Director). We believe that we can enter the market with this innovation and get back our monies. We believe in the returns. (InnoWEBS, Managing Director) providing a niche, enter the market and be one of the competitors... and make it as our niche market [as well as providing a new business opportunity]. (InnoWEBS, Managing Director).

The new business opportunity is the venture of InnoWEBS into manufacturing in the future which is expected to provide more business opportunities than construction. We want to be the manufacturer one day. We hope we will be the manufacturer and let someone else be the contractor. Now, the manufacturing part is still under the same entity although we have a different group of people working there (InnoWEBS, Head of Production, Design and Technical).

\subsection{Process improvement}

Construction firms also innovate because innovation simplifies construction work, which saves time, which in turn translates to cost savings, increased efficiency and productivity, which ultimately provides increased competitiveness. This is the message from our General Manager, as the head of the company, he must always make sure that there is efficiency and productivity - these two things must always be there, or else we can't compete outside. (InnoIBS, Manager Technology and Design). On site, innovative solutions to problems are necessary just to deliver the end product to the customer. For us, innovation is to overcome problems. It's all problem-solving and fire-fighting or so called innovation because we have to deliver the end product. (InnoIBS, Site Manager)

One driver for innovation is the project-based nature of the industry, which often imposes time constraints. InnoInfo is motivated to innovate to improve productivity in order to address four problems. The first is the lack of timely information, which inhibits informed decisions and thus leads to additional costs and delays decisions are often compromised and lead to some 10$20 \%$ time and cost overruns. (InnoInfo, Director)

The second problem is a lack of collaboration and coordination amongst stakeholders at the early stage of construction when the ability to control costs is higher and the costs of design changes are lower. The lack of alignment amongst stakeholders further compounds the problem (InnoInfo, Director). Thirdly, inefficient information exchanges between parties in construction projects that are in 2D or hardcopy formats cause rework and risk loss of accuracy (InnoInfo, Director; InnoInfo, Innovation Head). Fourthly, existing work tools and processes are unable to meet the needs of increasingly complex work and compressed time schedules as well as pressures to lower costs and increase productivity (InnoInfo, Director).

The main cause of these problems is the fragmented nature of the industry. Fragmentation is seen in the involvement of many players in any project easily, there can be 100 people [with] different roles and responsibilities without alignment [and] conflicts of interests. (InnoInfo, Innovation Manager). Clients can be one time off to own certain facility [i.e., once only or regular clients]. Consultants that advise developers generally want to make money, want to finish the job 
within their budget, specifications and time frame. We [construction firms] want things fast. Consultants charge based on the time in designing [and have] no motivation to minimize design time. Subcontractor scope is smaller, and they are specialists. All players' motivations are different. Their motivation is still time and cost. The different role and responsibilities tend to make them draw a line, e.g., this is my liability then this is my problem. (InnoInfo, Innovation Manager). The four problems are seen to cause inefficiency and ineffectiveness in the construction industry. We are not effective [and] have the lowest productivity compared to manufacturing. (InnoInfo, Innovation Manager).

InnoInfo was thus motivated to develop a ' $5 \mathrm{D}$ ' innovation based on product life cycle management (PLM) software to achieve high productivity. Manufacturing high productivity as model PLM is the way to go (best possible solution) that we think manufacturing has high productivity, and construction has the lowest productivity, so we want to relook and ask why it is that way for us. (InnoInfo, Innovation Manager)

InnoInfo's motivation to improve productivity is linked to its motivation to obtain competitive advantage. This is because low productivity further affects competitive advantage and branding. Maybe, at the end of the day, your gains are in terms of your branding and in terms of your differentiating between your competitors. When we were in Abu Dhabi, we were asked can you do [X]. We went home two years without any answers. But today we can answer; we are not the experts but we are able to deliver something. (InnoInfo, Innovation Head)

Another driver for innovation is client demand. InnoIBS' innovation resulted from a foreign client's demand for high safety standards (InnoIBS, Site Manager). The motivation was to overcome challenges for safety in construction (InnoIBS, Site Manager). The interaction between the problems caused by the nature of construction industry and firms' motivation to innovate is summarized in Figure 2.

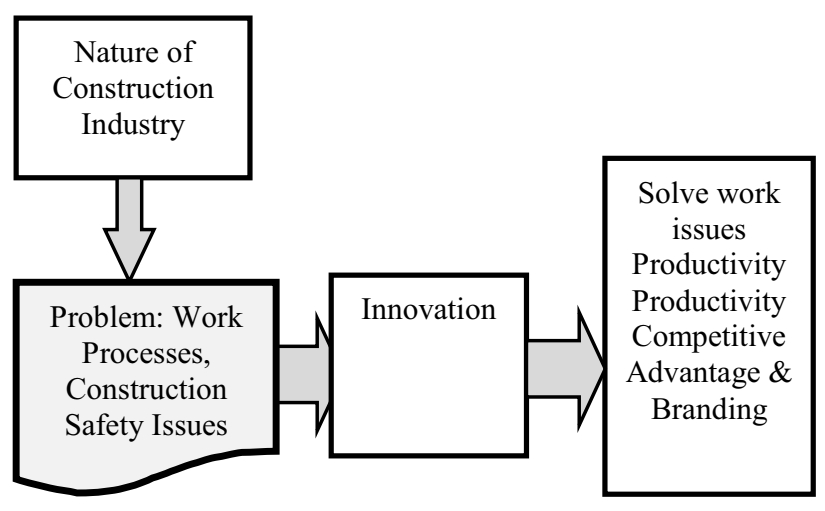

Figure 2: Opportunity- and Problem-Centric Motivation to Innovate, Construction Firms

\subsubsection{Positive effects of actors and networks}

In additional to the problem- and opportunity-centric motivations for innovation in construction, we found that actors motivated innovation. Top management provided leadership and direction, and showed commitment to innovation. The Board of Director's support for innovation is evident through the allocation of resources and investments in technology and R\&D, human capital development and collaboration initiatives with its external users.

In InnoInfo, the existence of a visionary and committed top management drives innovation. Innovation is driven from the top by the Director, through his vision for a virtual construction system, with the support of the company's Board of Directors. He had always had a dream of having something like virtual construction to be implemented. (InnoInfo, Innovation Manager).

The Director is a believer in information technology who has experience in customization. He strategized to keep R\&D alive in the company by creating an $R \& D$ team. He also sits in the Board of Directors and garners their support. The support of the Board of Directors is evident from their allocation of resources to the innovation. This support was appreciated by subcontractors. More importantly, the developer is committed because the innovation costs lots of money. (InnoInfo, Mechanical Subcontractor) and the site team. The resources are not cheap, so the management itself will have to be committed, willing to spend much money on R\&D. (InnoInfo, Site Project Team Member). Board support is important, not only because R\&D involves a lot of money, but also because there is negative return in the first few years if at company level you are making $\mathrm{RM}[\mathrm{XXX}]$ million and $\mathrm{RM}[\mathrm{X}-\mathrm{X}]$ million is in $\mathrm{R} \& \mathrm{D}$, the question mark is that are we spending the right way. But in technology advancement, the first few years are always negative not positive. (InnoInfo, Innovation Head). The top down vision serves as an important motivator for InnoInfo. You really have got to have top down vision, and enforcement mandatory all the way from the top. (InnoInfo, Innovation Head)

InnoInfra is motivated to innovate because of its Managing Director, who provides leadership in identifying a commercial opportunity and driving the innovation. It is the top management who will actually say there's a problem. Top management will involve a few key people from the functional team. (InnoInfra, Head Design \& Technical). Leadership and direction is very important. I greatly respect our MD because the D\&T Department only thinks of the technical part, sometimes not on commercial aspects whether the project is viable or not. (InnoInfra, Head D\&T)

InnoIBS is motivated to innovate by parent Group policy and practices. Firstly, the parent Group's top management has initiated continuous improvement activities which are implemented by the Group's Quality Unit. Secondly, the Group holds a half yearly quality forum, to which top management is strongly and visibly committed. Specific topics may be initiated by top management (Group Quality Manager), and the Chairman and 40 senior management personnel attend the event. The presence of top management indicates to staff that their ideas are important. This acts as a powerful form of recognition if at the [Group quality forum], staff need to come up with new ideas, but the 
ideas are not presented to top management, it does not work because the staff may think I have some new ideas and I just present to middle management and my ideas don't matter. This is a strong, good push factor. (InnoIBS, Group Quality Manager). In addition, top management approve staff members' ideas at the forum, and this is supplemented, again, with rewards and recognition of the staff concerned if they come out with new ideas, it ties to their salary bonuses and increment. (InnoIBS, Group Quality Manager). Top management are also involved in tracking the progress of implementation of the new ideas generated at forum other than presenting the status of the previous ideas bosses will also ask the Business Unit's Head at various meetings. The tracking of the progress of these ideas is done by top management, [the forum] and the Group Quality Management Unit. (InnoIBS, Group Quality Manager)

InnoInfra also benefits from internal actors' personal motivations to innovate. The Head of the Design and Technical (D\&T) Department innovates for two reasons. Firstly, innovation gives him professional satisfaction. We always look for things to perfect, to do things better, how to make it ... for innovation to happen. One thing is professional satisfaction. (InnoInfra, Head D\&T). Secondly, innovation challenges him to do things differently, and better. We always think, "The conventional way of doing things is like this, can it be done better?" We always challenge ourselves. (InnoInfra, Head D\&T)

InnoWEBS is motivated to innovate due to the personal motivation and training of the innovator. The Managing Director appreciates knowledge, enjoys the excitement of knowing and understands that the skills obtained from his $\mathrm{PhD}$ education enabled him to innovate. Likewise, the Head of Production, Design and Technical (HPDT) innovates because he enjoys innovating, it is one of his interests and he sees the result for end users. [I like] things that are different, simple yet serving the purposes, easy for end users to use and they can enjoy it. (InnoWEBS, HPDT)

\section{Discussion}

The motivations for innovation in the construction industry observed in this study are summarized in Table 3. Construction firms innovate for problem-centric or opportunity-centric reasons, like firms in the service sector. In addition, actors within construction firms motivate innovation through top management commitment, the leadership behaviours and attributes of innovation champions and the personal motivations of the innovators. Thus, the capability push of leaders has a strong effect on construction innovation. We also observed evidence of technology-push (InnoInfo and InnoWEBS). On the other hand, there was little demand pull in the construction subsectors we studied in Malaysia (only InnoIBS), contrary to the propositions made by Gann and Salter (2000).

\section{Conclusion}

This paper used the Tether and Metcalfe (2004) formulation of the SSI in services to examine the motivation for construction innovation in four Malaysian firms. The evidence showed that, not only is motivation for construction innovation problem and opportunitycentric, like that of the service sector, it is also led by actors within the construction firms themselves. Our results make two important contributions. Firstly, we confirm proposed similarities between innovation in the construction industry and innovation in the service industries. Further research on construction innovation is therefore likely to benefit from adoption or adaptation of models of service industry innovation. Secondly, we observed a personal, almost entrepreneurial commitment

Table 3: Motivation for Case Firms to Innovate, Compared With Extant Literature

\begin{tabular}{|l|l|l|}
\hline $\begin{array}{l}\text { Aspect of } \\
\text { Motivation }\end{array}$ & Details & Sources \\
\hline $\begin{array}{l}\text { Problem- } \\
\text { and } \\
\text { opportunity- } \\
\text { centric }\end{array}$ & $\begin{array}{l}\text { Firm seeks competitive } \\
\text { advantage-reputation, } \\
\text { work processes \& } \\
\text { ability to attract new } \\
\text { employees }\end{array}$ & $\begin{array}{l}\text { Slaughter (1998) } \\
\text { This paper }\end{array}$ \\
\cline { 2 - 3 } & $\begin{array}{l}\text { Firm seeks to improve } \\
\text { project and process } \\
\text { performance }\end{array}$ & $\begin{array}{l}\text { Project: Toole } \\
\text { (1998) } \\
\text { Process: New } \\
\text { finding in this paper }\end{array}$ \\
\hline Actor effects & $\begin{array}{l}\text { Leaders' capabilities } \\
\text { and formal and } \\
\text { informal roles, and } \\
\text { personal motivations } \\
\text { are strong determinants }\end{array}$ & $\begin{array}{l}\text { New finding in this } \\
\text { paper }\end{array}$ \\
\cline { 2 - 3 } & $\begin{array}{l}\text { Technology-push and } \\
\text { demand-pull are both } \\
\text { relevant }\end{array}$ & $\begin{array}{l}\text { Arditi et al. (1997), } \\
\text { Bossink (2004), } \\
\text { Tatum (1989) } \\
\text { This paper }\end{array}$ \\
\cline { 2 - 4 } & $\begin{array}{l}\text { Firm capability } \\
\text { capability-push } \\
\text { stronger than demand- } \\
\text { pull }\end{array}$ & $\begin{array}{l}\text { Gann (2000) } \\
\text { This paper, contrary } \\
\text { to Gann and Salter } \\
\text { (2000) }\end{array}$ \\
\hline
\end{tabular}

to innovation in our case study firms. This observation is new and, although it might be sample specific, seems sufficiently interesting to warrant further research. Regardless of firm size, structure and ownership, does successful innovation in the construction industry require entrepreneurial vision and personal commitment of a different kind to that required in other industries?

\section{References}

1. Abdul-Aziz, A. R., \& Wong, S. S. (2010). Exploring the internationalization of Malaysian contractors: The international entrepreneurship dimension. Construction Management and Economics, 28(1), 51-61. doi: 10.1080/01446190903460680

2. Acha, V., Gann, D. M., \& Salter, A. J. (2005). Episodic innovation: R\&D strategies for 
project-based environments. Industry and Innovation, 12(2), 255-281. doi: 10.1080/13662710500087990

3. Arditi, D., Kale, S., \& Tangkar, M. (1997). Innovation in construction equipment and its flow into the construction industry. Journal of Construction Engineering and Management, 123(4), 371-378. doi: 10.1061/(ASCE)07339364(1997)123:4(371)

4. Bossink, B. A. G. (2004). Managing drivers of innovation in construction networks. Journal of Construction Engineering and Management, 130(3), 337. doi: 10.1061/(ASCE)07339364(2004)130:3(337)

5. El-Mashaleh, M., O’Brien, W. J., \& Minchin Jr, R. E. (2006). Firm performance and information technology utilization in the construction industry. Journal of Construction Engineering and Management, 132(5), 499-507. doi: 10.1061/(ASCE)0733-9364(2006)132:5(499)

6. Gann, D. M., \& Salter, A. J. (2000). Innovation in project-based, service-enhanced firms: The construction of complex products and systems. Research Policy, 29(7-8), 955-972. doi: 10.1016/S0048-7333(00)00114-1

7. Hsieh, H.-F., \& Shannon, S. E. (2005). Three approaches to qualitative content analysis. Qualitative Health Research, 15(9), 1277-1288. doi: $10.1177 / 1049732305276687$

8. Koskela, L. J., \& Vrijhoef, R. (2001). Is the current theory of construction a hindrance to innovation? Building Research \& Information, 29(3), 197-207. doi: 10.1080/09613210110039266

9. Lim, J. Y. (2006). Stimulating construction innovation in Singapore by developing the national system of innovation. (PhD Dissertation), National University of Singapore, Singapore.

10. Ling, F. Y. Y. (2003). Managing the implementation of construction innovations. Construction Management and Economics, 21(6), 635-649. doi: $10.1080 / 0144619032000123725$

11. Malerba, F. (2002). Sectoral systems of innovation and production. Research Policy, 31(2), 247-264. doi: 10.1016/S0048-7333(01)00139-1

12. Malerba, F. (2004). Sectoral systems of innovation: Concepts, issues and analyses of six major sectors in Europe. Cambridge, UK: Cambridge University Press.

13. Malerba, F. (2006). Innovation and the evolution of industries. Journal of Evolutionary Economics, 16(1), 3-23. doi: 10.1017/CBO9780511493270

14. Malerba, F. (2007, September). Catching up in different sectoral systems. Paper presented at the GLOBELICS International Conference: Regional and National Innovation Systems for Development, Competitiveness and Welfare: the GovernmentAcademia-Industry Partnership, Saratov State Technical University, Saratov. http://csh.xoc.uam.mx/EII/globelicswp/wpg0801.pdf.

15. Malerba, F., \& Nelson, R. R. (2011). Learning and catching up in different sectoral systems: Evidence from six industries. Industrial and Corporate Change, 20(6), 1645-1675. doi: 10.1093/icc/dtr062

16. Nelson, R. R. (2008). What enables rapid economic progress: What are the needed institutions? Research Policy, 37(1), 1-11. doi: 10.1016/j.respol.2007.10.008

17. Oakland, J. S., \& Marosszeky, M. (2006). Total quality in the construction supply chain. Burlington, MA: Butterworth-Heinemann.

18. Reichstein, T., Salter, A. J., \& Gann, D. M. (2005). Last among equals: A comparison of innovation in construction, services and manufacturing in the UK. Construction Management and Economics, 23(6), 631-644. doi: 10.1080/01446190500126940

19. Samuelsson, P. (2003). Improvement processes in construction companies. In B. Atkin, J. Borgbrant \& P. E. Josephson (Eds.), Construction process improvement (pp. 225-239). Oxford, UK: Blackwell Science

20. Schumpeter, J. A. (1961). The theory of economic development: An inquiry into profits, capital, credit, interest, and the business cycle. (R. Opie, Trans.). New York: Oxford University Press. (Original work published 1934).

21. Seaden, G., Guolla, M., Doutriaux, J., \& Nash, J. (2003). Strategic decisions and innovation in construction firms. Construction Management and Economics, 21(6), 603-612. doi: $10.1080 / 0144619032000134138$

22. Shapiro, G. (1999). Inter-project knowledge capture and transfer: An overview of definitions, tools and practices CoPS Innovation Centre Working Paper No. 62 (pp. 42). Brighton: CoPS.

http://www.researchgate.net/publication/253518640 InterProject_Knowledge_Capture_and_Transfer_An _Overview_of_Definitions_Tools_and_Practices

23. Slaughter, E. S. (1998). Models of construction innovation. Journal of Construction Engineering and Management, 124(3), 226-231. doi:

10.1061/(ASCE)0733-9364(1998)124:3(226)

24. Tether, B. S., \& Metcalfe, J. S. (2004). Services and systems of innovation. In F. Malerba (Ed.), Sectoral systems of innovation: Concepts, issues and analyses of six major sectors in Europe. Cambridge, UK: Cambridge University Press.

25. Thomas, S. R., Lee, S.-H., Spencer, J. D., Tucker, R. L., \& Chapman, R. E. (2004). Impacts of design/information technology on project outcomes. Journal of Construction Engineering and Management, 130(4), 586-597. doi: 10.1061/(ASCE)0733-9364(2004)130:4(586)

26. Toole, T. M. (1998). Uncertainty and home builders' adoption of technological innovations. Journal of Construction Engineering and Management, 124(4), 323-332. doi: 10.1061/(ASCE)07339364(1998)124:4(323)

27. Toole, T. M., Hallowell, M., \& Chinowsky, P. (2013). A tool for enhancing innovation in construction organizations. Engineering Project Organization Journal, 3(1), 32-50. doi: $10.1080 / 21573727.2012 .717531$ 
28. Veblen, T. (1898). Why is economics not an evolutionary science? The Quarterly Journal of Economics, 12(4), 373-397. doi: 10.2307/1882952

29. Widén, K. (2006). Innovation diffusion in the construction sector. (PhD Dissertation), Lund University, Lund.

30. Widén, K. (2010). Construction Innovation: Statsbygg, the Driving Client. Lund, Sweden: Division of Construction Management, Lund University.

31. Yin, R. K. (2014). Case study research: Design and methods (5th ed.). Los Angeles: Sage. 